\title{
The Combination Therapy of Self-Surrender Exercise and Distraction Against Osteoarthritis Pain Scale of Elderly In Coastal Area
}

\author{
Syaifurrahman Hidayat*, Elyk Dwi Mumpuningtias, Ratna Indriyani \\ Faculty of Health Science, Wiraraja University Madura, Indonesia \\ * dayat.fik@wiraraja.ac.id
}

\begin{abstract}
A combination therapy of resignation and distraction techniques builds on relaxation, repeated prayer methods, and distraction from pain. For this reason, this study aims to provide a combination therapy of self-surrender training (LPD - latihan pasrah diri in bahasa) and distraction techniques to reduce the scale of osteoarthritis pain in Madurese elderly in coastal areas.

The research method used was quasi-experimental. This study used a control group design pre and post-test. The population in this study was the elderly with osteoarthritis pain in the coastal area of the Batang - Batang Public Health Center, Sumenep Madura. The sample of the study was elderly who experience osteoarthritis pain in coastal areas, with a purposive sampling technique using the inclusion and exclusion criteria approach, with a total sample of 70 elderlies. Data were analyzed using the Wilcoxon Signed Ranks Test and Mann-Whitney Test.

The results of this study indicate that the combination therapy of self-surrender training and distraction techniques is effective in reducing the level of osteoarthritis pain in the elderly living in coastal areas. The relaxing activity can be done both inside and outside the homes of the elderly who are mostly coastal areas.
\end{abstract}

Keywords: Self-Surrender Training, Distraction, Pain Scale 


\section{STRADA Jurnal Ilmiah Kesehatan}

DOI: $10.30994 /$ sjik.v9i2.425

ISSN: 2252-3847 (print); 2614-350X (online)

Vol.9 No.2 November 2020 Page.1212-1222

\section{BACKGROUND}

Old age is a natural stage of life in humans which is often associated with decreased bodily functions. Aging in a person is a natural process in humans. The most important stage in aging is getting old, where physiological changes and psychological deterioration in old age can cause a decline in the function of human body systems (Hidayat \& Mumpuningtias, 2018; Lukman et al., 2018). Physical decline results in damaged tissue systems in the elderly compromised to various diseases (Hidayat, 2014).

Pain in patients with osteoarthritis is generally chronic, hence it recurs frequently and is resistant to analgesics. Pain is a protective response that alerts the individual to actual or potential tissue damage. It is intended that the body's defenses react to the damaged tissue stimulus. Emotional distress and recurrence of illness can result from unresolved pain. Therefore, the nurse provides complementary therapy aimed at fulfilling a sense of comfort so that pain can be resolved (Karagülle et al., 2016; Yaban, 2019).

Pain is an individual experience, specifically describing pain that is emotional, cognitive and physical (acute and chronic). Humans explore the essence of pain using very personal responses. So that the elderly need to be encouraged to reflect on an understanding of pain. Individual perceptions of pain have an impact on pain management. Uncontrolled pain control in elderly patients can cause many physical complications (Nay \& Fetherstonhaugh, 2012; Rejeh et al., 2013).

Nonpharmacological pain management should be the nurse's main concern and priority in overcoming pain problems. Pain management in the elderly with osteoarthritis in the community depends on pain relievers. The use of non-pharmacological pain management is still rarely used, even though its use reduces the risk of side effects of drug use. This is due to the tradition of the Madurese coastal community to always consume pain medications. Likewise in lasia with chronic pain problems (Potter \& Perry, 2009; Ristia et al., 2018).

Behavior modification to reduce pain intensity can be in the form of combining relaxation and repetitive prayer methods. This form of compounding, if done correctly, will reduce levels of anxiety and worry and lead to feelings of peace (Susanti, 2014). Relaxation therapy is a complementary approach to analgesics in pain control (dos Santos Felix et al., 2019).

Nursing action efforts to solve the problem of pain intensity, namely distraction techniques. This technique aims to divert the client's attention to the pain that is felt, so that the elderly can meet their daily comfort needs. This condition is a relaxation that can reduce pain, where the activation of the parasympathetic nerves can stimulate the decline in all functions so that it can improve the sympathetic nervous system. (Prasetyo, 2010).

Self-surrender training and distraction techniques are expected methods to create a relaxation response. The ability to mobilize in the client's daily life activities is needed to influence self-efficacy (Susanti, 2014).

\section{METHODS}

This research is a quasi-experiment because the sample cannot be controlled and randomized (Sugiyono, 2017). The research design used a control group pre and post-test. The population in this study were 675 elderly who complained of osteoarthritis pain in the coastal area of the Batang-Batang Sumenep Madura Public Health Center. The sample in this study were elderly people who experienced osteoarthritis pain in coastal areas through the inclusion and exclusion criteria approach. To determine the occurrence of osteoarthritis, a clinical examination was carried out in July 2019 by determining the 


\section{STRADA Jurnal Ilmiah Kesehatan}

DOI: $10.30994 /$ sjik.v9i2.425

ISSN: 2252-3847 (print); 2614-350X (online)

Vol.9 No.2 November 2020 Page.1212-1222

respondent had osteoarthritis pain, namely if it fulfilled at least 3 of the 6 criteria, including age over 50 years, stiffness in the morning less than 30 minutes, occurrence of crepitus, tenderness in bones, changes in bone enlargement and palpation around the joints do not feel warm (Hidayat et al., 2018). The inclusion and exclusion criteria are as follows:

a. Inclusion criteria

1). Willing to sign an informed consent.

2). Able to communicate verbally and nonverbally

3). Respondents who during the study experienced joint pain on a scale of 3-8

4). The results of measuring the Mini Mental Status Examination (MMSE) with a score of 24-30 are no cognitive impairment

$5)$. The results of measuring the BDI (The Beck Depression Inventory) with a score of 0-7 are no or minimal depression and mild depression

b. Exclusion criteria

1). Respondents during the research process did not participate in routine activities for seven days of intervention.

2). Respondents entered the Hospital or Puskesmas (Opname)

3). Respondent Comma

The sampling technique was purposive sampling which was divided into two control groups and the treatment group. Methods of data analysis using statistical tests. First, the normality test was carried out using the Shapiro-Wilk test, then the Wilcoxon Signed Ranks Test and the Mann-Whitney Test were carried out. (Sugiyono, 2017).

\section{RESULTS}

\section{Respondent Characteristics}

a. Age

Table 1. Characteristics of Respondents by Age

\begin{tabular}{|c|c|c|c|}
\hline No & Age & Total & Percentage \\
\hline 1 & 60-74 Years (elderly) & 57 & $81,4 \%$ \\
\hline 2 & $75-90$ Years (old) & 13 & $18,6 \%$ \\
\hline 3 & $>90$ Years (very old) & 0 & $0 \%$ \\
\hline \multicolumn{2}{|c|}{ Total } & $\mathbf{7 0}$ & $\mathbf{1 0 0 \%}$ \\
\hline
\end{tabular}

Table 1 shows the majority of respondents aged 60-74 years (elderly) as many as 57 $(81.4 \%)$ and no respondents aged $>90$ years (very old).

b. Gender

Table 2. Characteristics of Respondents by Gender

\begin{tabular}{|c|lc|c|c|}
\hline No & \multicolumn{2}{|c|}{ Gender } & Total & Percentage \\
\hline 1 & Male & 10 & $14,3 \%$ \\
\hline 2 & Female & 60 & $85,7 \%$ \\
\hline \multicolumn{2}{|c|}{ Total } & $\mathbf{7 0}$ & $\mathbf{1 0 0 \%}$ \\
\hline
\end{tabular}

Table 2 shows that most of the respondents were female as many as $60(85.7 \%)$ of respondents and a small proportion of them were male as many as $10(14.3 \%)$ of respondents.

c. Education

Table 3. Characteristics of Respondents Based on education level

\begin{tabular}{|c|l|c|c|}
\hline No & \multicolumn{1}{|c|}{ Education } & Total & Percentage \\
\hline 1 & Not formally educated & 45 & $64,3 \%$ \\
\hline 2 & Equal to elementary school & 25 & $35,7 \%$ \\
\hline
\end{tabular}




\section{STRADA Jurnal Ilmiah Kesehatan}

DOI: $10.30994 /$ sjik.v9i2.425

ISSN: 2252-3847 (print); 2614-350X (online)

Vol.9 No.2 November 2020 Page.1212-1222

\begin{tabular}{|c|l|c|c|}
\hline 3 & Equal to middle high & 0 & $0 \%$ \\
\hline 4 & Equal to senior high & 0 & $0 \%$ \\
\hline \multicolumn{2}{c|}{ Total } & $\mathbf{7 0}$ & $\mathbf{1 0 0 \%}$ \\
\hline
\end{tabular}

Table 3 shows that most of the respondents did not have the final level of education or were not in school as many as $45(64.3 \%)$ and as many as $25(35.7 \%)$ had an equivalent education level SR / MI / SD.

d. Occupation

Table 4. Characteristics of Respondents by Occupation

\begin{tabular}{|c|l|c|c|}
\hline No & \multicolumn{1}{|c|}{ Occupation } & Total & Percentage \\
\hline 1 & Unemployed & 17 & $24,3 \%$ \\
\hline 2 & Farmer & 36 & $51,4 \%$ \\
\hline 3 & Merchant & 17 & $24,3 \%$ \\
\hline \multicolumn{2}{|c|}{ Total } & $\mathbf{7 0}$ & $\mathbf{1 0 0 \%}$ \\
\hline
\end{tabular}

Table 4 shows that most of the respondents work as farmers as many as $36(51.4 \%)$ and

$17(24.3 \%)$ respectively of the respondents work as traders and some do not work.

\section{e. Blood Pressure}

Table 5. Characteristics of Respondents Based on the results of blood pressure examination

\begin{tabular}{|c|l|c|c|}
\hline No & \multicolumn{1}{|c|}{ Blood Pressure } & Total & Percentage \\
\hline 1 & Optimum $(<120 / 180 \mathrm{mmHg})$ & 3 & $4,3 \%$ \\
\hline 2 & Normal $(<130 / 84 \mathrm{mmHg})$ & 31 & $44,3 \%$ \\
\hline 3 & High-Normal $(130 / 89 \mathrm{mmHg})$ & 15 & $21,4 \%$ \\
\hline 4 & $\begin{array}{l}\text { Mild/ Class 1 Hypertension } \\
(140 / 99 \mathrm{mmHg})\end{array}$ & 1 & $1,4 \%$ \\
\hline 5 & $\begin{array}{l}\text { Moderate/ Class } 2 \\
\text { hypertension }(160 / 109 \mathrm{mmHg})\end{array}$ & 7 & $18,6 \%$ \\
\hline 6 & $\begin{array}{l}\text { Severe/ Class 3 Hypertension } \\
(>180 />110 \text { mmHg) }\end{array}$ & 13 & $\mathbf{1 0 0 \%}$ \\
\hline \multicolumn{2}{|c|}{ Total } & $\mathbf{7 0}$ & \\
\hline
\end{tabular}

Table 5, the results of blood pressure checks on respondents showed that most of them had Normal blood pressure $(<130 / 84 \mathrm{mmHg})$ as many as $31(44.3 \%)$ and a small proportion had blood pressure results in the Class 1 mild hypertension category (140/99 $\mathrm{mmHg})$ as much as $1(1.4 \%)$ respondents.

Osteoarthritis Pain Scale in the elderly Before and After (Pre and Post)

Table 6. Differences in Osteoarthritis Pain Scale

\begin{tabular}{|l|l|c|c|c|c|}
\hline \multirow{2}{*}{ Pain Scale } & \multicolumn{2}{c|}{ Pre } & \multicolumn{2}{c|}{ Post } \\
\cline { 3 - 6 } \multicolumn{1}{|c|}{} & $\sum$ & $\%$ & $\sum$ & \% \\
\hline \multirow{4}{*}{$\begin{array}{l}\text { Treatment } \\
\text { Group }\end{array}$} & No Pain (0) & 0 & $0 \%$ & 0 & $0 \%$ \\
\cline { 2 - 6 } & Mild Pain (1-3) & 0 & $0 \%$ & 4 & $11,4 \%$ \\
\cline { 2 - 6 } & Moderate Pain (4-6) & 0 & $0 \%$ & 22 & $62,9 \%$ \\
\cline { 2 - 6 } & Severe Pain (7-8) & 25 & $71,4 \%$ & 9 & $25,7 \%$ \\
\cline { 2 - 6 } & Very Severe Pain (10) & 10 & $28,6 \%$ & 0 & $0 \%$ \\
\hline \multicolumn{2}{|c|}{ Total } & $\mathbf{3 5}$ & $\mathbf{1 0 0 \%}$ & $\mathbf{3 5}$ & $\mathbf{1 0 0 \%}$ \\
\hline
\end{tabular}




\section{STRADA Jurnal Ilmiah Kesehatan}

DOI: $10.30994 /$ sjik.v9i2.425

ISSN: 2252-3847 (print); 2614-350X (online)

Vol.9 No.2 November 2020 Page.1212-1222

\begin{tabular}{|l|l|c|c|c|c|}
\hline \multirow{4}{*}{$\begin{array}{l}\text { Control } \\
\text { Group }\end{array}$} & No Pain (0) & 0 & $0 \%$ & 0 & $0 \%$ \\
\cline { 2 - 6 } & Mild Pain (1-3) & 0 & $0 \%$ & 0 & $0 \%$ \\
\cline { 2 - 6 } & Moderate Pain (4-6) & 0 & $0 \%$ & 3 & $8,6 \%$ \\
\cline { 2 - 6 } & Severe Pain (7-8) & 29 & $82,9 \%$ & 31 & $88,6 \%$ \\
\cline { 2 - 6 } & Very Severe Pain (10) & 6 & $17,1 \%$ & 1 & $2,9 \%$ \\
\hline \multirow{2}{*}{ Total } & $\mathbf{3 5}$ & $\mathbf{1 0 0 \%}$ & $\mathbf{3 5}$ & $\mathbf{1 0 0 \%}$ \\
\hline
\end{tabular}

Wilcoxon Rank Test between Pre and Post Test of Treatment Group $=$ sig. $0,000(<0.05)$

Mann-Whitney U Test on the post-test between treatment and control group = sig. $0,000(<0.05)$

Table 6. shows descriptively in the experimental group before and after doing selfsurrender training and distraction techniques there are changes in respondents, namely a decrease in the pain scale. The pre-test showed that most of the respondents' pain scales were in the severe pain category (7-8) as many as 25 (71.4\%). After being given the treatment, the results of the post-test on the pain scale of the respondents in the moderate pain category (4-6) were $22(62.9 \%)$.

In the control group, descriptively showed that the respondents did not experience too much change which illustrated that the elderly experienced a severe pain scale (7-8) totaling $29(82.9 \%)$. After seven days without treatment, another examination was carried out. The pain scale results were obtained in the severe pain category (7-8) as many as 31 $(88.6 \%)$ of the respondents.

Based on the results of statistical tests in the experimental group before and after the treatment was carried out, it showed a significant change in the pain scale in the elderly. The results of the Wilcoxon rank test in the pre and post test of the experimental group $\mathrm{p}=0.000(\alpha<0.05)$, which indicates that statistically self-surrender training and distraction techniques can reduce the scale of osteoarthritis pain in the elderly.

To determine the difference in changes in the level of pain in the elderly, a comparison of the pain scale between the two groups with a degree of error of 5\% (0.05) was carried out using the results of the Mann-Whitney U test. It was obtained that the $p$ value $=0.000(\alpha<0.05)$, which means the difference was statistically significant between the two groups. So it can be concluded that there is a change in the osteoarthritis pain scale in the elderly who are given self-surrender training and distraction techniques.

\section{DISCUSSION}

In this study, the characteristics of the respondents were mostly female, $85.7 \%$ and male, $14.3 \%$. Based on the results of observations by researchers between the sexes of men and women, there is no difference in pain. The scale of pain felt by the coastal elderly is influenced by several factors. The first is the environment that has been cultured in the elderly in coastal areas with the daily activities of the coastal elderly, namely farming and trading. Both daily habits of doing menial jobs that affect the scale of pain in lasia in this study most of the elderly work as farmers as much as $51.4 \%$.

According to research Hidayat (2014) states that there is no difference in perception when experiencing pain between the sexes, namely between men and women. However, there are differences in behavioral responses to pain. This is due to the unfavorable 


\section{STRADA Jurnal Ilmiah Kesehatan}

DOI: $10.30994 /$ sjik.v9i2.425

ISSN: 2252-3847 (print); 2614-350X (online)

Vol.9 No.2 November 2020 Page.1212-1222

assumption that when men complain of pain, while women who complain of pain are the usual response.

The results showed that respondents aged 60-74 years (elderly) were $81.4 \%$ and there were no respondents aged $>90$ years (very old). This states that age in a person is a natural aging process that occurs in individuals. No one can prevent the aging process. So that it can have an impact on decreasing the function of the individual's body, including a decrease in health. The elderly will naturally experience a degenerative process. This process continues continuously eventually causing metabolic and structural distortions called degenerative diseases that cause the elderly to end their life with terminal episodes. (Hidayat et al., 2019).

Decrease in the musculoskeletal system in the elderly can result in changes in cartilage composition and water content which can affect joint load so that it can cause joint pain and deformity of the cartilage. Where the elderly who are over 70 years of age will produce autoantibodies so that the elderly are often found to experience joint pain (Musumeci et al., 2015; Wulan, 2015).

According to Parmelee et al. (2013) to examine the symptom structure of affective disorders in elderly with chronic health problems (osteoarthritis) is to explore crosssectional and longitudinal relationships. Exploration was carried out on the affective symptom cluster obtained by the results of the main health examination, including pain, functional disability, and health complaints that were felt by the elderly.

The results of the study in the experimental group stated that most of the pain scale in the severe pain category (7-8) was $71.4 \%$ and in the control group it was $82.9 \%$. This suggests that pain in patients with rheumatoid arthritis is a symptom that is often experienced by the elderly. According to Kushariyadi (2011) pain in the elderly with rheumatoid arthritis is a chronic systemic inflammatory disease. This condition is caused by the proliferation of the synovial membrane resulting in damage to the joints, ankylosis and deformity.

Physiological stress is a pain that can be shown on a pain scale so that it can determine the degree of pain experienced by the elderly. Pain in rheumatoid arthritis is due to inflammation which causes the release of chemical mediators in the body, so that other chemical mediators can stimulate pain. Prostaglandins can play a role in increasing pain caused by a stimulus (Smeltzer \& Bare, 2002).

Pain and inflammation in patients with rheumatoid arthritis occur due to an immunologic process in the synovia causing synovitis and pannus formation and ultimately damage to the joints. (Nugroho, 2009).

The results of the study on the pre-test showed that most of the pain scale was in the severe pain category (7-8) as many as $25(71.4 \%)$ and after being given treatment, the post-test results of the pain scale were in the moderate pain category (4-6) as many as 22 $(62,9 \%)$. Descriptively, this study shows that there is a decrease in pain in the elderly after doing self-surrender training and distraction techniques for 7 days. The treatment is given in accordance with standard operating procedures and is accompanied by researchers. These results also illustrate the persistence of the elderly in doing self-surrender training and distraction techniques. The treatment was given according to the daily conditions of the elderly where in this study it was carried out in the morning and at night before going to bed.

Pain management using pharmacological therapy, namely using analgesic or anesthetic drugs. The use of this class of drugs to interfere with stimuli and pain interpretation due to their action which suppresses the function of the thalamus and 


\section{STRADA Jurnal Ilmiah Kesehatan}

DOI: $10.30994 /$ sjik.v9i2.425

ISSN: 2252-3847 (print); 2614-350X (online)

Vol.9 No.2 November 2020 Page.1212-1222

cerebral cortex. Meanwhile, non-pharmacological pain management can be done independently by clients at home, in this case non-pharmacological therapies that can be done by the elderly, namely self-surrender training and distraction techniques. (Brunner \& Suddarth, 2013).

Based on the results of statistical tests from the results of pre and post measurements in the experimental group, it shows a significant difference in the pain scale of the respondents. The results of the Wilcoxon rank test $p=0.000(\alpha<0.05)$, which means that statistically self-surrender training and distraction techniques can reduce the scale of osteoarthritis pain in the elderly. This method creates calm and comfort, so that the client's ability to perform self-mobilization can affect the client's self-efficacy. The elderly need to do the exercises every day so that it becomes a daily habit (Ngatini et al., 2016)

According to Smeltzer and Bare (2002) relaxation can reduce pain levels. Relaxation helps ease pulmonary ventilation and increases oxygenation in the blood. Based on the research that has been done Sartika and Widastra (2009) there is an effect of relaxation techniques on the pain adaptation response. This opinion can prove that self-surrender training and distraction techniques that induce relaxation responses in individuals can reduce pain in the elderly with rheumatoid arthritis. Muscle tension is a pain response, relaxation can relieve pain by disrupting the complex cycle of pain processes. Selfsurrender training is part of the implementation form which provides relaxation to clients and performs dhikr accompanied by deep breathing exercises. The combination of lafazd that is pronounced in dhikr and deep breath can cause relaxation, with this response can reduce pain in the elderly. Relaxation exercises are a non-pharmacological method, are effective in relieving pain and therefore should be included in a regimen to control pain. (Topcu \& Findik, 2012).

The distraction technique used by the elderly in this study is a form of distraction of the elderly to another object, thereby reducing the response to pain and increasing pain tolerance. (Prasetyo, 2010). The form of distraction carried out by the elderly is by focusing their attention on the routine work of the elderly, including farming in the garden, harvesting coconuts, selling in the market and relaxing in the sand both inside and outside the house, where the area is mostly coastal areas.

According to Smeltzer and Bare (2002), distraction can divert the perception of pain experienced by the client by stimulating the descending control system in the human body. This causes the pain response to be transmitted less to the brain. So that distraction can be used as a form of exercise that focuses the client on a particular object when the client experiences pain.

Research in the control group descriptively shows the respondents did not experience too much change. It is illustrated that the elderly experienced a severe pain scale (7-8) amounting to $82.9 \%$. After seven days without treatment it was assessed and the pain scale results in the severe pain category (7-8) amounted to $88.6 \%$. These results indicate that the elderly in coastal areas still feel the same pain if the researcher does not intervene.

The impact of pain experienced by the coastal elderly has resulted in a decrease in sleep quality due to irregular sleep patterns, reduced appetite, irritability in social relations with the surrounding environment or irritability, difficulty doing daily activities, difficulty concentrating on work. The results of the Mann-Whitney $U$ test on the pain scale in the control group and the experimental group after treatment, it was found that the value of $p=$ $0.000(\alpha<0.05)$ means that there is a statistical difference. It was concluded that there was a decrease in osteoarthritis pain scale in the elderly in coastal areas using self-surrender training and distraction techniques. 


\section{STRADA Jurnal Ilmiah Kesehatan}

DOI: $10.30994 /$ sjik.v9i2.425

ISSN: 2252-3847 (print); 2614-350X (online)

Vol.9 No.2 November 2020 Page.1212-1222

According to Yuhbaba (2017) pain experience in an individual is an individual experience that is complex, unique, universal and subjective and personal, because the pain that is felt by an individual is very diverse and not the same between each individual. Selfsurrender training and distraction techniques are non-pharmacological forms of pain relief in reducing pain with the least possible side effect. It is also supported by the American College of Rheumatology (ACR), a guideline for the medical management of osteoarthritis (OA) that emphasizes the use of nonpharmacological interventions.

Submitting oneself to Muslims can be interpreted as tawakal, which is surrendering oneself to Allah and holding fast to Allah SWT. Trying with the intention of everything that happens is a divine destiny, surrendering to the creator for self-serenity. Viewed from an individual's point of view in doing self-surrender training, that is by surrendering oneself to Allah and surrendering oneself to other than Allah (Susanti, 2014). This can provide a very effective relaxation response in dealing with pain and providing a sense of comfort. Relaxation carried out sincerely with wholehearted concentration can reduce muscle tension, reduce feelings of boredom, and can reduce the pain that occurs.

Self-surrender training can be combined with distraction techniques, where the use of distraction techniques is often done by nurses in nursing intervention, namely by focusing the client's perception on other objects so that the pain is lost. This therapy uses individual imaginations that are planned with a lot of concentration in particular by doing daily activities or doing dhikr by resigning to the creator. This method is very suitable for respondents, who are mostly elderly, to have a positive effect in reducing pain.

Research result Rambod et al. (2014) states that Benson relaxation techniques can reduce pain intensity and improve quality of life in patients, so that Benson relaxation techniques can be used as part of a treatment practice to relieve pain intensity and improve quality of life in patients. The pain distraction technique is based on the reticular activity theory, which is to inhibit the occurrence of pain so that it blocks the pain impulses to the brain. Diversion of attention on pain by doing dhikr, listening to murrotal, watching television, closing your eyes while daydreaming about things that make you feel calm and comfortable.

According to Rejeh et al. (2013) the systematic relaxation technique was performed on elderly patients in the experimental group by reading casual sentences during recovery in ambulation after surgery. This relaxation technique can be incorporated into a treatment plan to reduce pain and anxiety and can increase the patient's independence in pain management control.

\section{CONCLUSSION}

There is a significant difference in the pain scale of the coastal area elderly before and after combination therapy of self-surrender training and distraction techniques in the experimental group and the control group.

There is a significant difference in the pain scale of the elderly in coastal areas after combination therapy of self-surrender training and distraction techniques in the control and experimental groups

The combination therapy of self-surrender training and distraction techniques are effective in reducing osteoarthritis pain scale in the elderly in coastal areas 


\section{STRADA Jurnal Ilmiah Kesehatan}

DOI: $10.30994 /$ sjik.v9i2.425

ISSN: 2252-3847 (print); 2614-350X (online)

Vol.9 No.2 November 2020 Page.1212-1222

\section{ACKNOWLEDGE}

1. Thank you to the Deputy for Strengthening Research and Development of the Ministry of Research and Technology / the National Research and Innovation Agency of the Republic of Indonesia as a funding source for the Community Partnership Program 2020 according to Decree Number 8 / EI / KPT / 2020.

2. Thank you to the Rector of Wiraraja University and LPPM of Wiraraja University for facilitating this research activity

3. The last, Thanks are conveyed to the Health Office of Sumenep Regency, especially for Batang-Batang Community Health Center who has been willing to give us permission to carry out this research

\section{REFERENCEC}

Brunner, \& Suddarth. (2013). Buku Ajar Keperawatan Medikal Bedah Edisi 8 volume 2. Jakarta EGC.

dos Santos Felix, M. M., Ferreira, M. B. G., da Cruz, L. F., \& Barbosa, M. H. (2019). Relaxation therapy with guided imagery for postoperative pain management: an integrative review. Pain Management Nursing, 20(1), 3-9. doi: https://doi.org/10.1016/j.pmn.2017.10.014

Hidayat, S. (2014). Dzikir Khafi untuk Menurunkan Skala Nyeri Osteoartritis Pada Lansia. Journal Of Health Science (Jurnal Ilmu Kesehatan), 1(1), 13-22. doi: doi.org/https://doi.org/10.24929/jik.v1i1.119

Hidayat, S., Hannan, M., Hasanah, L., \& Riska, U. (2018). Klenengan Music Therapy on Sleep Quality in Elderly Patients at Pratama Barokah Clinic. Journal of Medical Science and Clinical Research, 6(12), 107-112. doi: doi.org/https://dx.doi.org/10.18535/jmscr/v6i12.16

Hidayat, S., Hannan, M., \& Mulyadi, E. (2019). The Effectiveness of Self-Surrender Exercise and Dzikir Therapy in Improving the Quality of Sleep in A Nursing Home in Pasuruan, Indonesia Road. International Journal of Psychosocial Rehabilitation, 24(4), 5188-5197. doi: 10.37200/IJPR/V24I4/PR201617

Hidayat, S., \& Mumpuningtias, E. D. (2018). Terapi Kombinasi Sugesti Dan Dzikir Dalam Peningkatan Kualitas Tidur Pasien. Care: Jurnal Ilmiah Ilmu Kesehatan, 6(3), 219230. doi: http://dx.doi.org/10.33366/cr.v6i3.953

Karagülle, M., Kardeş, S., Dişçi, R., Gürdal, H., \& Karagülle, M. Z. (2016). Spa therapy for elderly: a retrospective study of 239 older patients with osteoarthritis. International journal of biometeorology, 60(10), 1481-1491. doi: https://doi.org/10.1007/s00484-016-1138-7

Kushariyadi. (2011). Asuhan Keperawatan Pada Klien lanjut Usia. Jakarta: Salemba Medika.

Lukman, M., Sihombing, F., \& Meilianingsih, L. (2018). Factors Associated with Death Anxiety in Elderly Batak Tribe who Live in Bandung. Jurnal Keperawatan Padjadjaran, 6(2), 139-145. doi: https://doi.org/10.24198/jkp.v6i2.694

Musumeci, G., Aiello, F. C., Szychlinska, M. A., Di Rosa, M., Castrogiovanni, P., \& Mobasheri, A. (2015). Osteoarthritis in the XXIst century: risk factors and behaviours that influence disease onset and progression. International journal of molecular sciences, 16(3), 6093-6112. doi: https://doi.org/10.3390/ijms16036093

Nay, R., \& Fetherstonhaugh, D. (2012). What is pain? A phenomenological approach to understanding. International Journal of Older People Nursing, 7(3), 233-239. doi: https://doi.org/10.1111/j.1748-3743.2012.00329.x 


\section{STRADA Jurnal Ilmiah Kesehatan}

DOI: $10.30994 /$ sjik.v9i2.425

ISSN: 2252-3847 (print); 2614-350X (online)

Vol.9 No.2 November 2020 Page.1212-1222

Ngatini, N., Wardaningsih, S., \& Afandi, M. (2016). Pengaruh Latihan Pasrah Diri dan Latihan Range of Motion Melalui Discharge Planning Terhadap Perubahan Activity Daily Living pada Pasien Stroke Iskemik. IJNP (Indonesian Journal of Nursing Practices), 1(1), 48-54. doi: https://hostpustaka.umy.ac.id/index.php/ijnp/article/view/3418/2977

Nugroho, W. (2009). Komunikasi Dalam Keperawatan Gerontik. Jakarta: EGC.

Parmelee, P. A., Harralson, T. L., McPherron, J. A., \& Schumacher, H. R. (2013). The structure of affective symptomatology in older adults with osteoarthritis. International journal of geriatric psychiatry, 28(4), 393-401. doi: https://doi.org/10.1002/gps.3837

Potter, \& Perry. (2009). Fundamental Keperawatan, Edisi 7 Buku 1. Jakarta: Salemba Medika.

Prasetyo, S. N. (2010). Konsep dan Proses Keperawatan Nyeri. Yogyakarta Graha Ilmu.

Rambod, M., Sharif, F., Pourali-Mohammadi, N., Pasyar, N., \& Rafii, F. (2014). Evaluation of the effect of Benson's relaxation technique on pain and quality of life of haemodialysis patients: A randomized controlled trial. International journal of nursing studies, 51(7), 964-973. doi: https://doi.org/10.1016/j.ijnurstu.2013.11.004

Rejeh, N., Heravi-Karimooi, M., Vaismoradi, M., \& Jasper, M. (2013). Effect of systematic relaxation techniques on anxiety and pain in older patients undergoing abdominal surgery. International journal of nursing practice, 19(5), 462-470. doi: https://doi.org/10.1111/ijn.12088

Ristia, A., Setiabudi, D., \& Mardiyah, A. (2018). The Effect of Parent Distraction Coaching Used The Toy on Pain Intensity of 1-5 Year-Old Children During Iv (Intravenous) Insertion. Jurnal Keperawatan Padjadjaran, 6(2), 146-156. doi: https://doi.org/10.24198/jkp.v6i2.391

Sartika, D. D., \& Widastra, N. M. (2009). Pengaruh Teknik Relaksasi Napas Dalam terhadap Penurunan Persepsi Nyeri pada Lansia dengan Artritis Reumatoid. Jurnal Keperawatan Soedirman, 4(2), 46-53. doi: http://dx.doi.org/10.20884/1.jks.2009.4.2.222

Smeltzer, S. C., \& Bare, B. G. (2002). Buku Ajar Keperawatan Medikal Bedah Brunner dan Suddarth (Ed.8, Vol. 1,2). Jakarta: EGC.

Sugiyono. (2017). Metode Penelitian Kuantitatif, Kualitatif, dan R\&D. Bandung Alfabeta CV.

Susanti, E. (2014). Pengaruh Latihan Pasrah Diri Terhadap Tingkat Stres dan Kadar Gula Darah pada Pasien Diabetes Melitus Tipe 2 di Rumah Sakit PKU Muhammadiyah Yogyakarta. IJNP (Indonesian Journal of Nursing Practices), 1(1), 78-91. doi: journal.umy.ac.id/index.php/ijnp/article/view/646

Topcu, S. Y., \& Findik, U. Y. (2012). Effect of relaxation exercises on controlling postoperative pain. Pain Management Nursing, 13(1), 11-17. doi: https://doi.org/10.1016/j.pmn.2010.07.006

Wulan, R. A. (2015). Pengaruh Terapi Kompres Air Hangat Terhadap Penurunan Skala Nyeri Sendi Pada Wanita Lanjut Usia Di Panti Tresna Werdha Mulia Dharma Kabupaten Kubu Raya. Jurnal Proners, 3(1), 1-14. doi: http://jurnal.untan.ac.id/index.php/jmkeperawatanFK/article/view/9438/9323

Yaban, Z. S. (2019). Usage of Non-Pharmacologic Methods on Postoperative Pain Management by Nurses: Sample of Turkey. International Journal of Caring Sciences, $12(1)$ 529-541.

doi: 


\section{STRADA Jurnal Ilmiah Kesehatan}

DOI: $10.30994 /$ sjik.v9i2.425

ISSN: 2252-3847 (print); 2614-350X (online)

Vol.9 No.2 November 2020 Page.1212-1222

https://www.internationaljournalofcaringsciences.org/docs/59_simsekyaban_12_1. pdf

Yuhbaba, Z. N. (2017). The Effect of Guided Imagination Distraction Techniques Through Green Color Reflection in Overcome Pain in Elderly with Rhematic Disease in Pslu Kasian District. Jurnal Kesehatan $d r$. Soebandi, 5(2), 373-381. doi: journal.stikesdrsoebandi.ac.id/index.php/jkds/article/view/96/88 